\title{
Searching for sustainable urban transport solutions for Africa: a case study of the Greater Johannesburg region in South Africa
}

\author{
J. Chakwizira \\ University of Venda, School of Environmental Sciences, South Africa
}

\begin{abstract}
The purpose of this paper is to undertake a critical review of existing urban transport interventions and innovations in Africa. The success factor that such measures have attained in seeking to reverse the trend of worsening and declining urban public transport services and infrastructure performance is assessed. Making use of the Greater Johannesburg region of South Africa as a case study, the urban transport hierarchy issues that make closing the loop difficult are identified and options for overcoming such obstacles discussed. The findings are based from a desktop analysis which is completed by an empirical research study in the Greater Johannesburg region carried consistently from 2007 up to 2011. These insights are complemented by key informants and transport stakeholder inputs. The aim of this longitudinal research is to seek to understand the complex and deeper issues that inform urban transport, policy, infrastructure and services dimensions. Overall, results confirm the consistent application of a mix of transport technology and non-technology solutions in the quest to solve urban transport problems in Africa. The tension and mismatch between transport infrastructure requirements and service gaps as contrasted with transport infrastructure and services budgeting and investment gap is an obvious weakness. Beyond transport plans and strategies, simultaneous application of transformative technology and related solutions is important if transport problems have to be reversed or significantly reduced. The need to implement more intelligent transport solutions today may serve developing countries from a worse transport situation in the future. Some of these transport technology innovations requiring serious consideration include a light rail; tram as well scope for underground train systems in the Greater Johannesburg region.
\end{abstract}

Keywords: urban transport, innovation, solutions, technology, Greater Johannesburg region, South Africa, Africa. 


\section{Introduction}

Africa is home to over 13 per cent of the world's total population and is growing at 2.7 per cent per year, which is the world's fastest rate $[1,2]$ The share of Africa's urban areas in relation to the average annual population growth is expected to more than double between the years 2000-2030 [3-5]. Weak, inappropriate and at times the absence of policies that link strongly land use, transport and economic development has led to urban sprawl, spatial fragmentation, long commuting and journey times, which accentuates the challenges of providing a world class urban transport and services system in urban areas [6-8]. Consequently, Africa's urban centres face instructive challenges regarding urban mobility. Over the last 30 years, African cities have experienced rapid motorization rates, which has resulted in chronic traffic congestion, extremely high levels of local pollution and poor levels of service for public transport compounded by inadequate transport infrastructure [7, 9, 10]. Investing in sustainable urban transport and services not only contributes to economic growth, but is also an important ingredient for enhanced human development [11-13].

In a study of 14 African cities conducted by the UN-Habitat [2], it was discovered that African cities share some common characteristics, namely: a growing urban population which is inadequately served by the existing transport system; existence of a declining standard of public transport; urban transport governance pain points regarding overlaps and conflicts among the agencies responsible for planning and implementing transport solutions; existence of a massive growth in the use of minibus services; an alarming growing dependence on private transport (cars and motorcycles); inadequate and deteriorating transport infrastructure especially road rehabilitation and maintenance and poor to non-existence of facilities for non-motorized transport (walking and bicycling).

\subsection{Purpose}

This paper presents a critical review of existing urban transport interventions and innovations in Africa with a view to drawing out the main challenges facing the sector and illustrating the different ways in which these have been addressed. This article further acknowledge that no two cities are the same, but at the same time hypothesises that there exists common strands in urban transport that can be harvested in reversing worsening and declining urban public transport services.

\section{Research methods}

The study makes use of a desktop study technique; expert interview guide to review African urban transport challenges and issues making use of the Greater Johannesburg region in South Africa was adopted. The region provides a crosssection of typical African cities in that it shares both the characteristics of a modern African metropolis (the Gauteng city region itself) with the 
characteristics of typical large urban areas (Johannesburg and Tshwane metropolitan city regions themselves) as well as giving insight to the peri-urban transport problems (Hammanskraal and Pretoria north city region).

\subsection{Study area}

Africa's size, geography, cultural setting, administrative structure, and national macroeconomic framework are different from one country to the next. Different African countries have responded to the challenge of urban transport in different ways.

\subsection{Urban transport growth and development pathways in Africa}

Urban areas have evolved differently while being supported by urban transport systems tailored for their unique conditions. While diversity in approaches has traces in the history, culture, place and people inhabiting urban geographic spaces, common development paths are discernible. These relate to responding to the "urbanisation and motorisation revolution" through either adopting a "car based approach" or a "non-car based approach". However, a variety of hybrids models along the continuum exists. Figure 1 presents the urban transport and development growth scenarios. This raises matters regarding what future direction urban transport infrastructure and services African cities are likely to take.

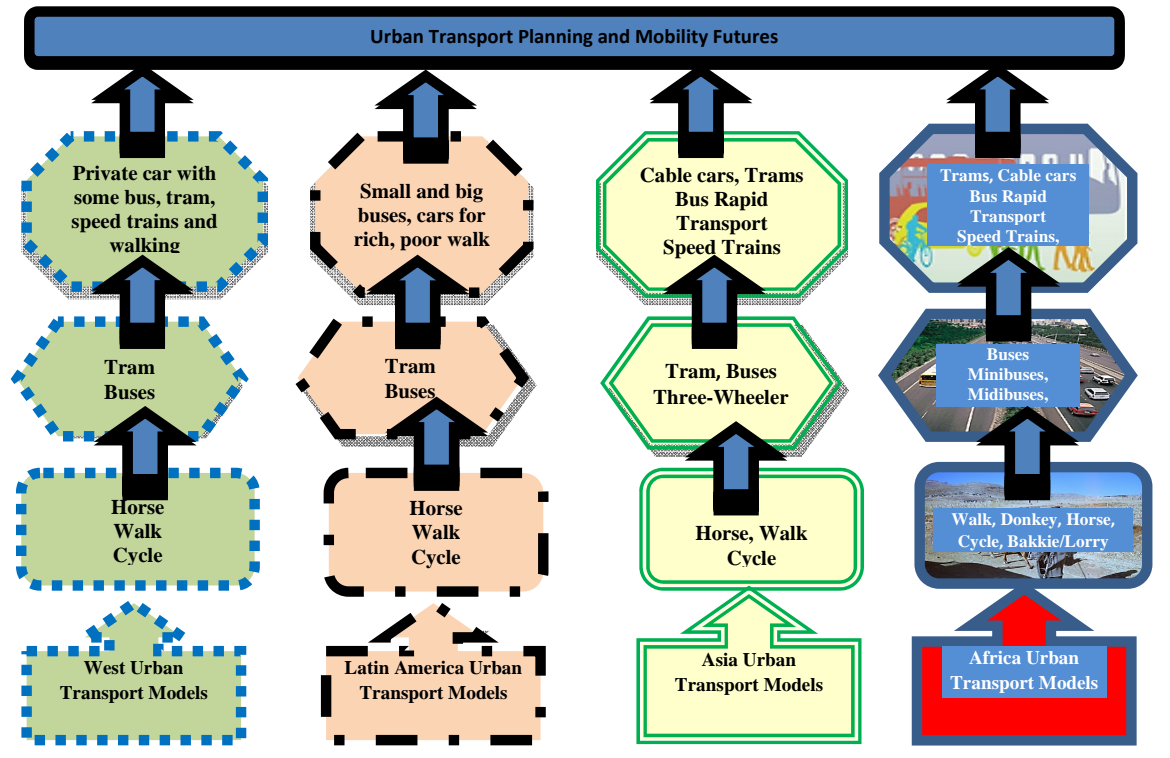

Figure 1: $\quad$ Urban transport growth and development pathways. 


\subsection{Analytical sustainable urban transport framework}

Figure 2 presents an analytical sustainable transport framework adopted in guiding the analysis and generation of potential intervention options. The next generation urban transport solutions should be anchored in a transport life cycle analysis.

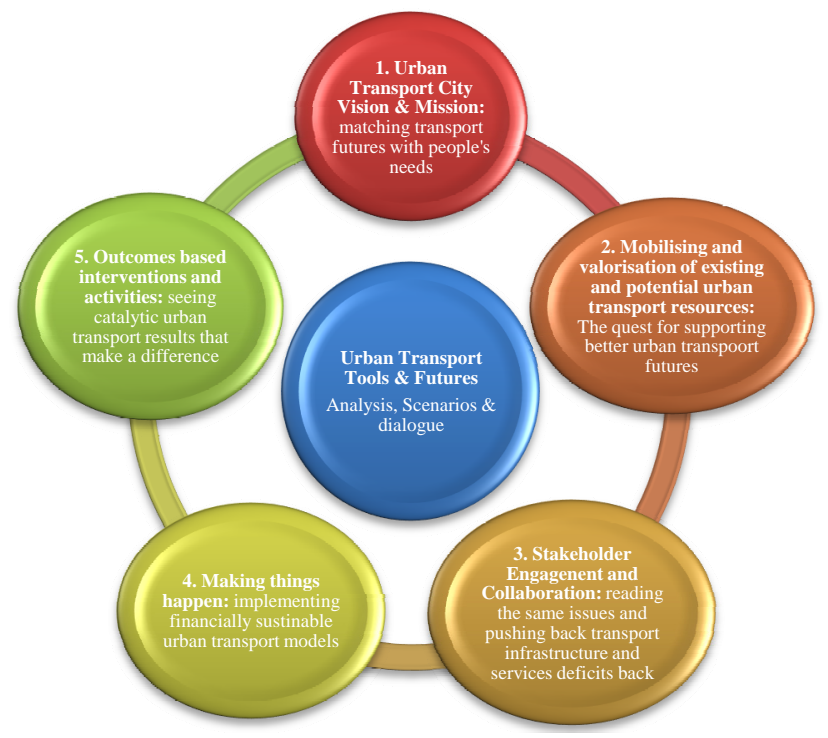

Figure 2: $\quad$ Analytical sustainable urban transport framework.

\section{Discussion of study findings and results}

This section discusses the study findings in terms of key informants interviews conducted at the Knowledge Management Africa International Conference held in Senegal, Dakar $27^{\text {th }}-29^{\text {th }}$ September 2009. 20 purposively sampled transport and knowledge experts from Africa were asked key questions regarding urban transport in Africa. These results of the expert interviews are interpreted and reconciled with study findings of the Johannesburg region in South Africa as analysed from the following latest dataset, namely the Johannesburg Integrated Development Plan Household Transport Surveys [11], Gauteng Household Community Surveys [12] and Statistics South Africa income and expenditure household surveys [13]. In Johannesburg, a randomized household sample size of 284 was used making use of Macor sample size formulae.

\subsection{Age and sex distribution of respondents}

The distribution of questionnaires between males and females was almost even for the 20 expert interviews. However, more males beyond the age of 40 participated while the female age group was capped at 36 years. This is 
symptomatic of gender bias and occupation patterns with the transport sector being strictly male dominated. However, more females below 25 than males participated in the survey reflecting the transformation and new initiatives of making the transport sector gender neutral. Figure 3 presents the age and sex distribution of expert interview study respondents. For the Greater Johannesburg randomized household surveys region, $53 \%$ of the respondents were female while $47 \%$ of the respondents were male.

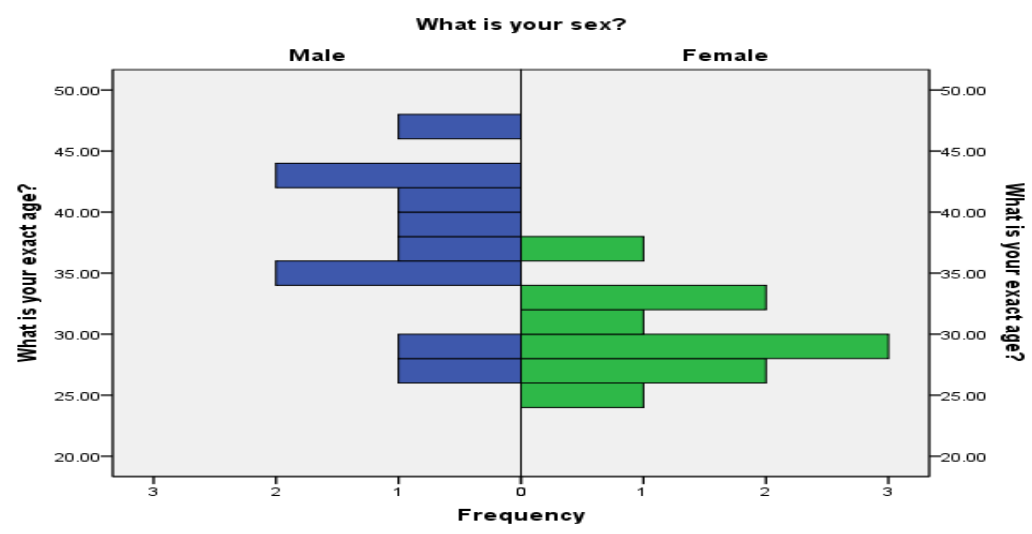

Figure 3: Age and sex distribution of respondents.

\subsection{Respondents' countries of origin}

Participants who responded came from East, West and southern Africa. This was a fair spread of countries in Africa although no participant participated from North Africa. The transport problems and issues in these countries mirror and parallel those happening and occurring in the Greater Johannesburg region of South Africa. Figure 4 presents expert interview participants' country of origin. In the Greater Johannesburg region survey, out of the 384 survey respondents

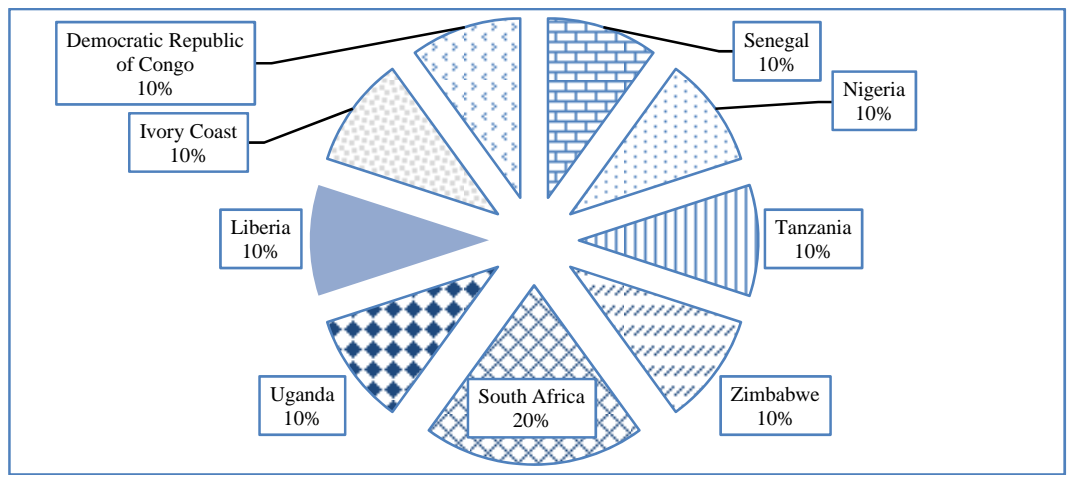

Figure 4: Where do you come from? 
(all based and living in South Africa), 62\% were from South Africa, 28\% were from Zimbabwe, $9 \%$ were from Nigeria, $4 \%$ were from Ghana, 3\% were from Kenya, $2 \%$ were from Somali and $1 \%$ were others. There was indeed a spread and balance of respondents with at least some exposure to different city models and functions beyond the Greater Johannesburg region cities.

\subsection{Respondents' cities of residence}

Table 1 presents an overview of which cities did the expert interview respondents come from. Major urban centres in East, West and Southern Africa were represented.

Table 1: Which city do you live in?

\begin{tabular}{|l|l|l|l|l|l|}
\hline \multicolumn{2}{|c|}{} & Frequency & Percent & $\begin{array}{l}\text { Valid } \\
\text { Percent }\end{array}$ & $\begin{array}{l}\text { Cumulative } \\
\text { Percent }\end{array}$ \\
\hline Valid & Abidjan & 2 & 10.0 & 10.0 & 10.0 \\
\cline { 2 - 6 } & Conakry & 2 & 10.0 & 10.0 & 20.0 \\
\cline { 2 - 6 } & Dakar & 2 & 10.0 & 10.0 & 30.0 \\
\cline { 2 - 6 } & Dar es Salaam & 2 & 10.0 & 10.0 & 40.0 \\
\cline { 2 - 6 } & Kampala & 2 & 10.0 & 10.0 & 50.0 \\
\cline { 2 - 6 } & Kinshasa & 2 & 10.0 & 10.0 & 60.0 \\
\cline { 2 - 6 } & Lagos & 2 & 10.0 & 10.0 & 70.0 \\
\cline { 2 - 6 } & Harare & 2 & 10.0 & 10.0 & 80.0 \\
\cline { 2 - 6 } & Johannesburg & 4 & 20.0 & 20.0 & 100.0 \\
\cline { 2 - 6 } & Total & 20 & 100.0 & 100.0 & \\
\hline
\end{tabular}

\subsection{Headline urban transport infrastructure and services challenges in African cities}

Table 2 presents a summary of the major urban transport infrastructure and services problems in urban African cities as indicated by the expert interviews. Lack of political leadership and will power to tackle the problem at $35 \%$ was the most frequent problem. This had resonates in governance and integrity issues [10]. It is not surprising that governance systems and legislative drawback was also singled out at $15 \%$. This also supports the factor of historical legacy and or recent conflict as accounting for poor urban transport delivery services and products at $25 \%$. Overall the inefficient public transport have strong roots and links with the colonial policies and interventions as well as the nature of investment and low priority afforded the development of a World class transport system then. The current challenge is to reverse and transform the skewed transport landscape and replace it with a new generation of sustainable transport model for African cities [6, 7, 13]. The same problems of fragmented and dispersed urban settlements that are difficult to services and traverse exist in the Greater Johannesburg region of South Africa [8, 9]. Gauteng's road network has to cope with an annual traffic increase rate of $7 \%$, with 1.8 million drivers and 2.8 million registered vehicles [14].

The cities used as case studies, Johannesburg, Pretoria and Ekurhuleni in the Greater Johannesburg region are fast growing cities. All the cities are growing rapidly, and, as populations have grown, so have city boundaries, which now 
Table 2: What are the key urban transport infrastructure and services challenges in your city?

\begin{tabular}{|l|r|r|r|r|}
\hline & Frequency & Percent & \multicolumn{1}{|c|}{$\begin{array}{c}\text { Valid } \\
\text { Percent }\end{array}$} & $\begin{array}{c}\text { Cumulative } \\
\text { Percent }\end{array}$ \\
\hline $\begin{array}{l}\text { Inefficiency in the transport system } \\
\text { is considered normal }\end{array}$ & 4 & 20.0 & 20.0 & 20.0 \\
\hline $\begin{array}{l}\text { Lack of political leadership and } \\
\text { willpower to tackle the problems } \\
\text { head on }\end{array}$ & 7 & 35.0 & 35.0 & 55.0 \\
\hline $\begin{array}{l}\text { Historical legacy and or recent } \\
\text { conflict }\end{array}$ & 5 & 25.0 & 25.0 & 80.0 \\
\hline $\begin{array}{l}\text { Planning authorities hamstrung in } \\
\text { implementing capacity [resource } \\
\text { limitations] }\end{array}$ & 1 & 5.0 & 5.0 & 85.0 \\
\hline $\begin{array}{l}\text { Urban transport governance systems } \\
\text { and legislative drawbacks }\end{array}$ & 3 & 15.0 & 15.0 & 100.0 \\
\hline Total & 20 & 100.0 & 100.0 & \\
\hline
\end{tabular}

extend into contiguous areas, often managed by different local governments. This same observation was made by Kumar and Barret [7] regarding expansion of a metropolitan area over several jurisdictions greatly complicating the task of planning, regulating, and operating urban transport services in Africa as in the industrialized world. African transport authorities have traditionally remained weak, fragmented, and under-funded hence they are unable to maintain existing services or to plan for expansion $[1,8,13]$. This raises the question as to whether are African cities transport requirements out-stripping resource capacity or not? Paved roads are just one-third of the average for cities in the developing world $[7,15,19]$. The average travel time to work in the Greater Johannesburg Area has increased from 41.5 minutes in 1995 to 50 minutes in 2003, representing a $17 \%$ increase over eight years [15].

\subsection{Regulatory measures to reverse existing urban transport problems in Africa}

Respondents indicated that regulatory measures could be used as formulae for arresting the urban transport challenges and crisis (refer to table 3 for the expert interview results). Traffic congestion came out a strong problem in the cities represented by the respondents; this is also a key problem in the Greater Johannesburg region $[8,9,15]$. The adoption of intelligent transport management systems had the highest percentage at 25\%. Respondents felt that with new advances in transport technology such as the GPS systems in place cities should become better navigable and communicate information regarding congested routes, routes were accidents had occurred and empower drivers to make better decisions that help in reversing grid-lock conditions. The city of Johannesburg has already started initiatives in this regard [9]. In terms of travel time, Lombard et al. [15] present that as a result of roadway congestion; many commuters have changed departure times to work to either earlier or later than traditional peak. Given, these multiple forms of dysfunctional urban public transport it is critical 
to find innovative ways to resolve the challenges. The respondents indicated that speed limits be reduced, parking space be rationed and properly priced [from residential, industrial to commercial] and strict enforcement of pedestrian as necessary (all at 20\%). However the respondents were quick to highlight that most of these regulatory measures require a clear transport policy regarding car ownership and public transport. In all the countries, it was noted that no car retirement and capping system was in place $[9,10]$. Moving forward practical ways of addressing this gap have to be developed [7, 14-17].

Table 3: Name any regulatory measures that you believe can reverse existing problems?

\begin{tabular}{|l|r|r|r|r|}
\hline & Frequency & Percent & \multicolumn{1}{|c|}{$\begin{array}{c}\text { Valid } \\
\text { Percent }\end{array}$} & $\begin{array}{c}\text { Cumulative } \\
\text { Percent }\end{array}$ \\
\hline $\begin{array}{l}\text { Introduction and strict enforcement of } \\
\text { restraint measures such as pedestrian } \\
\text { zones, car free zones etc }\end{array}$ & 4 & 20.0 & 20.0 & 20.0 \\
\hline $\begin{array}{l}\text { Adoption of Traffic Management } \\
\text { Measures e.g. ITS }\end{array}$ & 5 & 25.0 & 25.0 & 45.0 \\
\hline $\begin{array}{l}\text { Regulation and rationing of parking space } \\
\text { supply e.g. maximum parking limits }\end{array}$ & 3 & 15.0 & 15.0 & 60.0 \\
\hline $\begin{array}{l}\text { Establishing and gazetting low carbon } \\
\text { emission zones in the city }\end{array}$ & 4 & 20.0 & 20.0 & 80.0 \\
\hline $\begin{array}{l}\text { Instituting new speed restrictions in built } \\
\text { up and city centres e.g. 30km an hour }\end{array}$ & 4 & 20.0 & 20.0 & 100.0 \\
\hline Total & 20 & 100.0 & 100.0 & \\
\hline
\end{tabular}

\subsection{Economic instruments for managing city traffic better}

The debate is often raised that what is best in taming traffic in cities between regulations (laws), economic measures (money/pricing) and institutions (people and mindsets) $[5,6,16,17]$. The study responded were also requested to answer to this debate (refer to table 4). $50 \%$ of the respondents indicated that full cycle parking pricing [paying parking at home, offices, in city centre etc.] was an effective way of discouraging and changing motor driving habits and patterns. The example of Singapore was given as a success story [6, 9]. Road pricing e.g. tolling of specific routes and or during peak hours was highlighted as one way of shifting modal split in favour of mass transport systems that are better users of road space. The respondents indicated this choice at $25 \%$. In Gauteng region, the e-tolling project is set to be implemented by April month-end of 2012. This is despite resistance and objections being raised by labour unions and civil transport groups. The climate change theme also featured with respondents indicating that one way for the transport sector to contribute was through introducing incentives for cleaner or green cars while those with dirty or polluting cars will be heavily penalized in terms of vehicle emission tariffs. The Department of Transport in South Africa is currently working on a model towards modalities of carbon reduction in the transport sector. Table 4 presents the expert interview results. 
Table 4: $\quad$ Identify any potential economic instruments that can be used in managing better city traffic?

\begin{tabular}{|l|r|r|r|r|}
\hline & Frequency & Percent & \multicolumn{1}{|c|}{$\begin{array}{c}\text { Valid } \\
\text { Percent }\end{array}$} & $\begin{array}{c}\text { Cumulative } \\
\text { Percent }\end{array}$ \\
\hline Road pricing e.g. during peak hours & 6 & 30.0 & 30.0 & 30.0 \\
\hline Tax incentives e.g. for cleaner vehicles & 4 & 20.0 & 20.0 & 50.0 \\
\hline $\begin{array}{l}\text { Parking pricing e.g. off-street and on- } \\
\text { street parking }\end{array}$ & 10 & 50.0 & 50.0 & 100.0 \\
\hline Total & 20 & 100.0 & 100.0 & \\
\hline
\end{tabular}

\subsection{The role of information technology in solving urban transport problems}

Table 5 presents the potential role that information technology can play in solving urban transport problems in Africa (as reflected by the expert interviews). The respondents argued that economic and regulatory instruments and interventions are not enough. What underlines a sustainable transport solution is mindsets and people's transport culture [1]. The respondents proceeded to indicate how information technology could be used in the fight against urban traffic and transport problems in Africa. $40 \%$ of the respondents noted that public transport awareness campaigns are important in shaping and reshaping people's thinking around and towards urban transport. In addition, $35 \%$ of the respondents indicated that eco-training for city drivers and freight trucks is essential. $25 \%$ of the respondents indicated that the activity should not be left as a government only initiative. The private sector can assist with promotion of mobility weeks, flexible working hours etc. This confirms earlier study findings that discovered and concluded that both government and nongovernment sectors should collaborate and partner in the fight for sustainable and suitable solutions for African cities [2, 6, 7, 14, 19].

Table 5: $\quad$ Are there any information related measures that can assist in solving urban transport problems?

\begin{tabular}{|l|r|r|r|r|}
\hline & Frequency & Percent & \multicolumn{1}{|c|}{$\begin{array}{c}\text { Valid } \\
\text { Percent }\end{array}$} & $\begin{array}{c}\text { Cumulative } \\
\text { Percent }\end{array}$ \\
\hline $\begin{array}{l}\text { Public Awareness Campaigns e.g. } \\
\text { participation in car free days, Transport } \\
\text { Month, Mobility Weeks etc. }\end{array}$ & 8 & 40.0 & 40.0 & 40.0 \\
\hline $\begin{array}{l}\text { Driver Training/Eco-training e.g. for } \\
\text { city drivers, haulage drivers etc. }\end{array}$ & 7 & 35.0 & 35.0 & 75.0 \\
\hline $\begin{array}{l}\text { Promotion of mobility in companies } \\
\text { e.g. employer passes, flexible working } \\
\text { hours }\end{array}$ & 5 & 25.0 & 25.0 & 100.0 \\
\hline Total & 20 & 100.0 & 100.0 & \\
\hline
\end{tabular}

\subsection{Contribution of transport technology to resolving urban transport problems in Africa}

Table 6 presents respondents' thinking regarding how technology can contribute to addressing transport problems in Africa (as highlighted by the expert 
interviewers). $35 \%$ of the respondents indicated that green buses, trams and trains are the key solution. BRT is becoming more popular in Africa as seen by new systems in Johannesburg, South Africa; Lagos in Nigeria, and soon in Dar es Salam, Tanzania, with plans for several other cities [1, 8, 9]. The Gautrain train is expected to cut the number of cars on the N1 Ben Schoeman Highway by $20 \%$, or 135000 passenger trips per day by 2010 [8, 9, 14, 20]. 30\% indicated that transport infrastructure and services should comply with green infrastructure and construction methodologies. The promotion of green tender procurement system in the transport sector was also identified as one way of contributing towards a low carbon emission economies in Africa. Research and science institutions should be supported to research in new materials that are more carbon neutral/friendly.

Table 6: What is the potential role and contribution that technology can advance in resolving urban transport problems in Africa.

\begin{tabular}{|c|c|c|c|c|}
\hline & Frequency & Percent & $\begin{array}{c}\text { Valid } \\
\text { Percent } \\
\end{array}$ & $\begin{array}{c}\text { Cumulative } \\
\text { Percent }\end{array}$ \\
\hline $\begin{array}{l}\text { Promotion of greener technology tender } \\
\text { procurement systems e.g. green } \\
\text { procurement for state tenders }\end{array}$ & 3 & 15.0 & 15.0 & 15.0 \\
\hline $\begin{array}{l}\text { Promotion of the construction of green } \\
\text { infrastructure }\end{array}$ & 6 & 30.0 & 30.0 & 45.0 \\
\hline Promotion of green logistics in industry & 2 & 10.0 & 10.0 & 55.0 \\
\hline $\begin{array}{l}\text { Promotion of green cars, buses, trains } \\
\text { and trams }\end{array}$ & 7 & 35.0 & 35.0 & 90.0 \\
\hline $\begin{array}{l}\text { Promotion of green science and } \\
\text { technology institutions, research and } \\
\text { practices }\end{array}$ & 2 & 10.0 & 10.0 & 100.0 \\
\hline Total & 20 & 100.0 & 100.0 & \\
\hline
\end{tabular}

\section{Conclusion}

History shows that a balanced mix of transport modes should be supported by a city's road infrastructure. Otherwise, a massive gridlock occurs, costing up to 4 to 5 percent of GDP a year - simply unaffordable for many countries [1]. The economic costs further increase when the impacts of air pollution and climate change are taken into account [2, 4]. Moreover, without facilities to protect them from high-speed traffic, pedestrians and cyclists are disproportionally killed on roads which follow an outdated car-centric model. Africa, and sub-Saharan Africa in particular, has an opportunity to leapfrog and add non-motorized transport to the existing urban road expansion.

\subsection{Recommendations}

The study major finding is to propose a "wave or "V" urban transport improvement motion model for strengthening urban public transport in African cities. The "wave or "V" urban transport improvement motion model consists of stepped measures to construct, upgrade, maintain and rehabilitate new and old 
infrastructure, implement advanced and state of the art appropriate traffic management systems, enhance service quality, and increase network access and coverage. The proposed strategy, that I term the "wave or "V" urban transport improvement motion model is illustrated in figure $4[7,8,14,19]$.

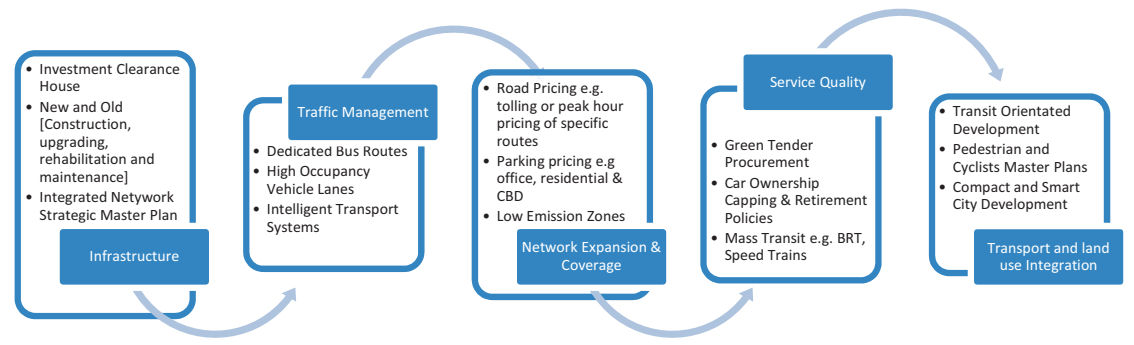

Figure 5: "Wave or "V" urban transport improvement motion model.

African cities in attempting to deflect continent wide grid-lock need to develop and implement robust and sustainable universal transport systems that increase travel choice and modes of travel for different segment of the society. Given the importance of the transport sector in national and the global economy, applying green technologies and processes in urban mobility will be a crucial component of inclusive urban transport comprehensive investment strategies towards more sustainable ways of production of goods and services in the entire economy. It is also further acknowledged that proven technology exists for mass transit options using alternative energies, but these are all still quite expensive, especially for the developing world.

\section{References}

[1] Kim P. and Jong de R. (2010). High time to change road investment patterns in Africa - Fast-growing cities throughout sub-Saharan Africa should support walking and cycling by investing in road infrastructure for non-motorized transport. UNEP, Urban World, 2010.

[2] UN-Habitat (2010). A new perspective on sustainable urban mobility in Africa, Nairobi Kenya, ISBN: 978-92-1-132324-5.

[3] Trans-African Consortium (2010b): Overview of Public Transport in SubSahara Africa. http://www.uitp.org/knowledge/projects-details.cfm?id =444. [22.12.2011].

[4] Trans-African Consortium (2010a). : Public Transport in Sub-Saharan Africa. Major trends and Case Studies. http://www.uitp.org /knowledge/pdf/PTinSSAfr-Majortrendsandcasestudies.pdf. [01.09.2010].

[5] United Nations. (2005). Financing Urban Shelter: Global Report on Human Settlements 2005. New York.

[6] World Bank. (2002). "Cities on the Move: World Bank Urban Transport Strategy Review.” Washington, DC.

[7] Kumar A. and Barrett F. (2008). Stuck in Traffic: Urban Transport in Africa, World Bank, Washington, DC. 
[8] Chakwizira J., Bikam P. and A.T. Adeboyejo (2011). "Functional and dysfunctional urban mass transportation systems in the greater Gauteng region of South Africa” pp.737-748, Sustainable Development and Planning V (2011) Edited by C. A. Brebbia and E. Beriatos, ISBN 978-184564-544-1; ISSN: 1746-448X (Print); ISSN: 1743-3541 (online) WIT Press, Southampton, Boston.

[9] Chakwizira J., Bikam P., Dayomi M. and Adeboyejo A.T. (2011). Some Missing Dimensions of Urban Public Transport in Africa: Insights and Perspectives from South Africa, the Built and Human Environment Review, Volume 4, Special Issue 2. 2011, pp. 56-84.

[10] Chakwizira J., Mashiri M. (2009). The contribution of transport governance in socio-economic development in South Africa, Sustainable Transport: 28th Annual Southern African Transport Conference (SATC) 2009, Pretoria, South Africa, 6-9 July 2009, pp. 1-18 ISBN: 9781920017392

[11] JIDP (2008). Johannesburg Integrated Development Plan, Johannesburg, South Africa.

[12] Gauteng. (2007). Gauteng household travel survey data, obtained from the City of Johannesburg, City of Johannesburg, South Africa.

[13] Statistics South Africa. (2008). Income and expenditure of households 2005/2006: Analysis of results. Statistics South Africa, Pretoria. ISBN No. 978-0-621-37635-7.

[14] Shaw A. (2005) Public Transport: Gautrain Can Show Way For SA, Business Day Final 05 September 2005 p. 11.

[15] Lombard, M. Cameron, B. Mokonyama, M. Shaw, A. (2007). Report on trends in passenger transport in South Africa. Development Bank of Southern Africa, South Africa. ISBN: 1-919692-95-9.

[16] SSATP (Sub-Saharan Transport Policy Program). (2005). “A Study of Institutional, Financial and Regulatory Frameworks of Urban Transport.” SSATP Working Paper 82.Washington, DC. July.

[17] Kumar, Ajay, and Fanny Barrett. (2006). "Urban Transport Sector Performance Indicators: Descriptive Manual.” Staff paper prepared as part of the Africa Infrastructure Country Diagnostic, Africa Region, World Bank, Washington, DC.

[18] Chakwizira J., Mokonyama M., Mashiri M., Marrian B. (2008). Sustainable Public Transport in South Africa, SACN, September 2008, Braamfontein, Johannesburg.

[19] Carruthers R, Ranga R. K., and Siobhan M. (2008). "Improving Connectivity: Investing in Transport Infrastructure in Sub-Saharan Africa.” Background Paper 7, Africa Infrastructure Country Diagnostic, World Bank, Washington, DC.

[20] Chakwizira J. (2007). The Question of Congestion and Decongestion in the Greater Johannesburg Area: Some Perspectives, 26th Annual Southern African Transport Conference and Exhibition, Pretoria, South Africa, 9-12 July 2007: ISBN 1-920-01702-X, pp. 499-51. 